\title{
In-service teachers' reaction to a training program of Task-based language teaching: A case study of English language teachers in Vietnam
}

\author{
Nguyen Anh Thi ${ }^{1,2}$, Nguyen Phuong Bao Tran ${ }^{2}$ \\ ${ }^{1}$ (Linguistics, Faculty of Arts/ KU Leuven, Belgium) \\ ${ }^{2}$ (School of Foreign Languages/ Can Tho University, Vietnam)
}

\begin{abstract}
The current study examines how Vietnamese English as Foreign Language (EFL) teachers, who have been using traditional teaching methods for years, react to a training program of Task-based language teaching (TBLT) in their authentic classrooms. Three teachers and 180 students participated in this study. Data were collected via classroom observations and semi-structured interviews and then analyzed qualitatively afterwards. The results indicate that the teachers could not be able to manipulate TBLT principles and perform their TBLT teaching roles properly. In addition, the semi-structured interviews reveal that the teachers had positive attitudes towards TBLT, that was TBLT could promote learners' motivation and language use ability. However, TBLT also appears to be impeded by the great influence of traditional teaching methods as well as form-based teaching syllabuses and assessment. Other obstacles are learners' negative learning attitudes and large-sized classes. The results also present that all teachers advocated the possibility of TBLT implementation if certain changes could be made.
\end{abstract}

Keywords: Authentic classroom, implementation, teachers' attitudes, teacher training, Task-based language teaching

\section{Introduction}

During the past decades, language education in Vietnam has been attenuated, especially in terms of language teaching methodology. In an effort to find an alternative approach which can potentially replace the traditional form-based and teacher-dominated approaches, and which can effectively promote learners' language proficiency, a number of innovations have been diffused. In 2004, for instance, a Presentation-PracticeProduction (PPP) method was officially introduced into the language teaching curriculum because this method was believed to satisfy the current needs: PPP reflected a notion of "practice makes perfect", common in many skills (Thornbury, 1999) and it provided a clear teacher role, in accordance with power relations often found in Asian classrooms (Skehan, 2003). However, regarding the goal of promoting learners' language proficiency, educationalists, up to date, have realized that PPP is not successful as expected (Ellis \& Shintani, 2014). For one, PPP is too linear and behaviorist in nature. Thus, it does not take learners' linguistic syllabus and readiness into consideration (Ellis, 2003). Also, PPP relies heavily on the use of decontextualized and meaningless drills (Wong \& Van Patten, 2003). In fact, PPP focuses too much on accuracy rather than fluency (Thornbury, 1999; Skehan, 2003).

With regard to this problematic issue, the Vietnamese Ministry of Education and Training (Moet) decided to take action which aimed to give rise to a policy shift from a rule-based instruction into a more communicative-based instruction, stating that, "Communicative skills are the goals of the teaching of English at the secondary school while formal knowledge of the language serves as a means to the end" (Moet, 2006, p.6) or "learner-centered, communicative task-based" language teaching (Moet, 2006, p. 14) must be a priority. In 2008 , to promote the move towards a more communicative approach the Vietnamese Prime Minister issued Decision No 1400/QD-TTg on Approving a national plan called "Teaching and Learning Foreign Languages in the National Formal Education System in the period of 2008-2020" which aimed to develop a foreign language curriculum in the nation-wide level, especially for English. However, all efforts have not led to an effective improvement until now.

Obviously, language teachers play an important role in the success or failure of a diffusion of an innovation (Markee, 1997; Borg, 2003; Van den Branden, 2009a; Ellis \& Shintani, 2014). However, the number of research into the effects of pre-/in-service teacher training on teachers' actual actions in their authentic classroom is still scarce. This paper, therefore, attempts to examine how Vietnamese EFL teachers, who have been using traditional form-based approaches for years, react to a training of TBLT in terms of classroom-based practice. Accordingly, recommendations for an effective teacher training program towards the implementation of TBLT will be suggested. 


\section{Literature Review}

\subsection{Traditional teaching method (TTM) versus Task-based language teaching (TBLT)}

TTM is featured as teacher-centered education in which classroom activities and interaction are dominated by the teacher while TBLT is said to be learner-centered (Long, 1985, 2015; Ellis, 2003; Ellis \& Shintani, 2014; Van den Branden 2006; Van den Branden, Bygate \& Norris, 2009; Van den Branden 2016). In a learner-centered approach, the learners are fully supported and encouraged to take care of their own learning process and self-reflect what they are learning. In TBLT, the teacher and learners are joint decision-makers in all classroom activity. Instead of being controlled as in the case of TTM, TBLT learners, according to their needs and capacities, are allowed to freely engage in discussing, sharing and evaluating their own learning outcomes.

For teaching, TTM is said to segment language into discrete units of linguistic features (grammatical rules and lexical items) for explicit instruction. In sharp contrast, TBLT takes holistic, functional and communicative tasks as its main unit of analysis (Van den Branden, 2006). The learners are expected to "induce knowledge about smaller units from their actual performances and communication challenges in complex situations" (Van den Branden et al., 2009, p. 2). In this respect, learners are given real-life communicative tasks which are often taken place in functional situations. In addition, they are fully supported and encouraged to engage in intensive interaction, and as a result, they are claimed to learn the target language more effectively (Long, 1985, 2015).

Another notable difference is that TTM is mainly concerned with the idea that explicit form-based instruction must be a primary focus in language classes. While in TBLT, there is a strong focus on meaning, stating that communication must be the center of all pedagogical activities and teaching procedures (Van den Branden et al., 2009). Long $(1985,2015)$ argues that second language learners need to be provided with functional tasks and have to be involved in intensive interaction and real-world language use. In the same vein, Van den Branden (2016) states that learners need to be exposed to meaningful input from the very early stages of second language acquisition on. By focusing on meaning while communicating and interacting with their peers, learners' motivation and interest can be successfully promoted. It is worth considering that although TBLT emphasizes communicative effectiveness in real-world tasks, it does not preclude form-based activities or teacher-led activities (Ellis, 2003, 2009; Van den Branden et al., 2009; Norris, 2009, 2016; Ellis \& Shintani, 2014; Van den Branden, 2016). Rather, it "allows, even encourages - a focus on form in view of optimizing the learning potential of task-based educational activities" (Van den Branden et al., 2009, p. 6). As such, explicit form-based instruction can be considered as an integral part of TBLT (Van den Branden, 2016). Unlike a focus on forms in TTM, which means that particular linguistic items such as grammar rules or lexical items must be firstly introduced through explicit instruction, then practiced in isolation under the form of grammar-based exercises before being memorized automatically by the learners, the term focus on form, in a TBLT perspective, refers to the teaching of linguistic items within the context of communicative activities. This typically occurs when the teacher reacts to form-focused issues the student is struggling with during the performance of communicative tasks. For instance, during the negotiation for meaning (Long, 2015), the learner can be supported by the teacher and other learners to deal with new linguistic items without interrupting the flow of the communication. Van den Branden (2016) advocates that the teacher may correct learners' errors or scaffold their problem-solving in an explicit way to help them figure out problems while understanding or producing an utterance.

Regarding assessment, assessment, in a TTM perspective, mainly tests the isolated application of memorized data such as grammatical patterns or words at an extremely low level of critical thinking normally taken in the form of paper-and-pencil tests using multiple choice, matching items or true/false statements. Clearly, such tests primarily measure what the learners know about the language rather than what they can actually do with the language. Nevertheless, task-based language assessment mainly aims to measure learners' ability to complete target tasks - task-based performance (Long, 2015; Norris, 2016) - up to criterion. Norris (2016) argues that TBLT assessment evaluates the extent to what learners can use the language to express meaning within a well-defined communicative context. Brindley (1994, p.76) states that assessments based on communicative tasks are valid because, 'they attempt to replicate 'real life' language use situations, which is ultimately what communicative language teaching and assessment are concerned with'. Similarly, Paltridge (1992) considers tests task-based if they include communicative activities (target tasks) performed by learners.

The role of the teacher in TTM and in TBLT is also extremely different. Due to the principles of learner-driven education (Van den Branden et al., 2009) and meaning-focused communication through the performance of tasks (Ellis \& Shintani, 2014), the teacher in TBLT has to shift the role from being a knowledgeprovider or a controller (common in TTM) to being a mediator for language education throughout the lesson (Van den Branden, 2016). For instance, the teacher might take the role as a person who selects or determines the focus of the classroom activity (during the pre-task phase) or he can work as a proficient and knowledgeable partner who organizes, supports and motivates learners during the task-performance phase. Also, the teacher can take the role of an effective assessor who evaluates learners' task performance and their learning progress by 
using a variety of meaningful tasks, i.e., criterion-referenced tests (Long, 2015; Norris, 2016) in the post-task phase. Van den Branden (2016) highlights the concern that the TBLT teachers should also be involved in research-doing activity as (action) researchers and reflective practitioners, and as a result, the teachers can be considered as important change agents in innovations. However, these promising roles of the teacher are not stated in TTM.

\subsection{Relationship between teacher cognitions and teacher actions}

Obviously, what language teachers do in the classroom is not fully inspired by the theoretical knowledge to which they are exposed through the diffusion of an innovation or in training programs. Rather, the teachers tend to rely on their collective and individual teaching experience (Cochran-Smith \& Lytle, 1993) together with a sense of ownership with respect to the innovation (Bailey, 1992) to deal with their teaching. The teachers often modify tasks given by the syllabus designers to suit their own beliefs on what they think is best for their teaching and learners (Van den Branden, 2016). Borg (2003, p. 81) conducted a study reviewing a selection of research into teacher cognition, stating, "teachers are active, thinking decision-makers who make instructional choices by drawing on complex, practically-oriented, personalized, and context-sensitive networks of knowledge, thoughts and beliefs". Van den Branden (2006) advocates that what the language teachers actually do in the classroom is also inspired by ideas about different teaching-related aspects, i.e., language education and learning, curriculum, school contexts, learners and so on.

In language education, research into the relationship between teacher cognition and teacher action in practical teaching conditions has received mixed results (see Borg, 2003). One of the possible reasons can be explained in the incongruence between teachers' espoused beliefs and what they actually do: beliefs-in-action (Borg, 2001). Van den Branden (2006) states that in authentic classrooms, it is not only the teacher cognition which promotes actions but the actions taken in the classroom also feed their cognition. In other words, this kind of relationship "is not unilateral, but interactive" (Van den Branden, 2006, p. 219). From this perspective, he suggests a list of factors which might explain the inconsistencies between what the teachers think, know, believe and what they actually act in the classroom. These include contextual constraints such as time limits, lack of appropriate teaching aids, conflicting beliefs, and finally conflicts between beliefs and skills (for instance, the teacher tries to allow learners the initiative to solve the problem themselves but lacks interactional skills to support them).

Clearly, the road from teacher cognition to teacher action is complicated and difficult to observe, even unobservable because what the teachers do in the classroom is not straightforward, but mediated by a number of factors and chaos (Van den Branden, 2009b). Therefore, research into the field of teacher cognition as well as factors contributing to the relationship between teacher cognition and teacher action is also one for continued consideration.

\subsection{Teacher training of TBLT in Vietnam}

The role of the teacher has been considered to be extremely important in any pedagogical changes (Hattie, 2012). Vongalis-Macrow (2007, p. 436) mentions, "what teachers do and how they react to educational change is significant in determining the outcomes of change". Regarding TBLT adaptation, it is not an exception to highly evaluate the important role of the teacher (Prabhu, 1987; Willis, 1996; Samuda, 2001; Van den Branden, 2006, 2009a, 2016; Van den Branden et al., 2009). Ellis \& Shintani (2014) agree that one of the most crucial factors contributing to the success of TBLT can be seen in the roles adopted by the teacher. However, in an attempt to introduce TBLT into the teaching curriculum, researchers have realized that a number of challenges and difficulties related to teachers occurred (Adamson \& Davison, 2003; Zhang, 2007; Samuda \& Bygate, 2008; Barnard \& Nguyen, 2010). Littlewood (2007) conducted a study in the context of Asia, including Vietnam. He realized that the teachers demonstrated a lack of confidence in implementing TBLT due to the limited capacity and practical skills. Barnard \& Nguyen (2010) conducted a study investigating how the Vietnamese teachers who had been trained of TBLT actually reacted in practical teaching. They found, "these teachers are faced with the problems of realizing an ambitious curriculum for which they had not been adequately trained" (p. 82).

In order to find out more evidence on the issue of teacher training towards TBLT implementation in Vietnam, this study, therefore, aims to examine how the language teachers, who have been using a traditional form-based teaching syllabus for years react to the training of TBLT in their authentic classroom practices. In addition, their concerns as well as beliefs towards the advantages and possibility of TBLT implementation in the context of Vietnam are also considered. 
In-service teachers' reaction to a training program of Task-based language teaching: A case study..

\subsection{Research questions}

The current study investigated the following research questions:

1. To what extent do Vietnamese EFL teachers, who have been using a form-based teaching syllabus for years, react to a training of TBLT in their actual teaching practices?

2. What are the teachers' concerns about the implementation of TBLT?

3. What are the teachers' beliefs towards the advantages and possibility of TBLT implementation?

\subsection{Context and participants}

\section{Method}

Three EFL teachers teaching at Can Tho university, Vietnam agreed to participate in this study. One of them was male and the others were female. Their age range was between 27 to 30 years. They all have been teaching English at tertiary level for at least 4 years. Prior to participating in this study, these teachers were officially trained about TBLT by one of the researchers who was supposed to know TBLT very well. About the training procedures, the teachers, firstly, were informed about TBLT theoretically. They were given all kinds of TBLT-related materials, i.e., books, articles and so on for reading purposes. Next, the teachers were asked to participate in a training workshop which was limited to one meeting of four hours. The training mainly aimed at presenting basic pedagogical teaching principles of TBLT as well as the role of the teacher in a TBLT classroom. For the trainer, he tried to illustrate his ideas of what makes a perfect TBLT approach. He also provided specific examples with the hope to make a transfer from what the teachers acquired during the training session into their teaching practices afterwards. In addition, a total of 180 non-English majored learners who were randomly arranged into six classes by the university also participated in this study. The learners had been studying English for at least 7 years at secondary level and they were currently taking a course of General English - level 2, a conditional subject required in their study program. The learners were considered to be comparable in English language proficiency because they were all tested by the university before registering the course.

\subsection{Design}

This is a qualitative research study. Data were collected via classroom observations to investigate how the teachers actually react to the training program towards the implementation of TBLT. A semi-structured interview activity (see Appendix 1) was conducted to investigate teachers' beliefs of TBLT after they had experienced it. Unlike conventional interviews which might limit participants' responses due to their psychological pressure or time limitation, the semi-structured interview allows participants to have more freedom and time to divulge their ideas in a safe way, resulting in reliable data. In order to compare the extent that the teachers change after the training, they were each asked to teach a similar reading lesson to two different classes by using two different methods: TBLT and TTM. In the next paragraph, we will describe the two teaching conditions in detail.

\subsubsection{The TTM condition}

With regard to teaching sequences, the lesson, in TTM, was designed in a fixed and systematic way following a three-phase sequence: opening, drilling and closing. In the opening phase, the teacher, after a greeting activity, immediately introduced the lesson content to the learners. A list of discrete linguistic items (grammar rules and vocabulary) associated with the topic was also provided, followed by the teacher's explicit instruction. In the drilling phase, the teaching time was fully devoted to learners' isolated practice of form-based reading. After this stage, the teacher corrected the reading exercises and gave feedback on learners' output explicitly. In the closing phase, the teacher introduced follow-up activities to offer learners free discussion about relevant topics (average from 3-5 minutes). In case of lacking time, the teacher was also allowed to skip this activity. The lesson was ended by the teacher giving learners homework and reminding them to review what they had been taught. It is noted that in the TTM, the interaction flow was unidirectional from the teacher to the learners. The teacher controlled all classroom activities and delivered explicit knowledge to learners. Learners were assumed as passive receivers who were expected to digest and memorize the knowledge given by the teacher. On the whole, the TTM primarily focused on accuracy rather than fluency.

\subsubsection{The TBLT condition}

TBLT teaching involved the integration of different language skills: the learners were given materials for reading or listening comprehension. Then, they were asked to write a communicative message pertaining to the text that they had read or listened to, or were asked to discuss or report on what they had read or written to their peers or groups. By doing so, all four skills were involved and integrated. About the teaching sequences, there were three phases consisting of a pre-task phase, a task-performance phase and a post-task phase (Willis $\&$ Willis, 1996). The pre-task phase began with a teacher-led introduction of a topic or a situation, followed by 
the learners discussing and sharing with the help of the teacher. In this stage, the learners were asked to work in groups. The learners' prior knowledge and personal motivation as well as interest were also strongly encouraged. During the task-performance phase, the learners were asked to work on tasks individually and then discuss or evaluate task outcomes with their peers. Clearly, interactional support occurred during this stage (and also throughout the lesson) played a crucial role in helping learners double check, revise and evaluate their own learning progress. In the post-task phase, learners were asked to report what they had performed. At this stage, the teacher also explicitly introduced form-focused activities to offer learners opportunity to practice certain linguistic rules or vocabulary. In addition, the teacher could correct learners' error and give necessary feedback. It was also worth considering task repetition or evaluation in this stage. On the whole, the primary focus was said to place on meaning through all lesson phases.

\subsection{Task}

In this study, because the main theme of the lesson was about tourism, thus, four reading texts describing four famous destinations in Vietnam were intentionally chosen (see Appendix 2). Three task types including a true or false statements task, a multiple choice questions task and a comprehension questions task were used. The choice of these task types was due to their popularity in the current teaching curriculum and also based on the assumption that learners were closely familiar with. In each task, there were five questions which were used to test learners' understanding of the reading texts. While teaching, the teachers (in the TBLT condition) were allowed to be flexible in using the given materials, and they were also encouraged to design extra tasks for their teaching providing that they could still satisfy the lesson goals.

\subsection{Data collection and analysis}

Data were collected from classroom observations and a semi-structured interview activity. Observations of teachers' performance in the TTM and the TBLT were conducted via video-recordings. In order to find out how well the teachers could apply the TBLT approach, the researchers did transfer the recorded data which was fundamentally based on the analysis of (1) basic TBLT teaching principles and (2) key roles of the teacher proposed in TBLT literature. In addition, semi-structured interviews of the three teachers were conducted. The interviews involved asking teachers to comment on three issues: concerns, advantages and the possibility of TBLT implementation in the context of Vietnam.

\section{Results}

Results of the current study offer a framework for investigating: teachers' reaction to a TBLT training program; teachers' concerns and teachers' beliefs towards advantages and the possibility of TBLT implementation.

\subsection{Teachers' reaction to TBLT training}

The results indicate that although the teachers had been carefully trained about TBLT, they failed to apply this approach into their authentic classroom practices in both terms of teaching principles and the role of teacher. In general, the teachers violated principles of meaning-focused, learner-centered and holistic education through all phases of the lesson. In addition, form-focused and teacher-led activities were totally ignored. Regarding the teacher role, all teachers showed their weaknesses in performing their mediating roles (Van den Branden, 2016). For the sake of clarity, we will present the observed data with regard to teachers' actual performances in three phases of a TBLT lesson: pre-task, during-task performance and post-task performance.

In the pre-task phase, the three teachers opened the lesson by introducing a communicative activity for learners' involvement and discussion. By doing this, the teachers may actively involve individual learners into the lesson and also prepare necessary inputs, i.e., instructions, ideas, key vocabulary for them to perform the task in the next phase: task-performance. Teacher 3, for instance, decided to use a drawing activity to start the lesson. In order to arouse learners' interest and involvement, teacher 3 organized a group work activity and intentionally invited one volunteer in each group to come to the blackboard, together with the teacher, drawing a map of Vietnam. At the same time, others learners were asked to do a similar task with their groups, followed by intensive discussion about topic of the lesson - tourism. In this respect, teacher 3 could directly involve learners into the lesson, on the one hand, and successfully offer them an opportunity to contribute their ideas, on the other hand. Moreover, learners' prior knowledge and enthusiasm for the tasks could be activated. In contrast, the results indicate that teachers 1 and 2 , whom we videotaped, failed to organize the opening activity in a communicative way. Both teachers were observed to quickly end up the activity and move to the next phase (task-performance) while the learners were still enthusiastically working on the discussion. Clearly, the teachers broke the communication flow among learners and potentially reduced their enthusiasm and interest in involving in the tasks.

During the task-performance phase, the data illustrate that all teachers failed to maintain TBLT teaching principles. As a result, they could not be able to show their role as a mediator in teaching. Clearly, the 
teachers tended to over-emphasize on lexical-grammatical accuracy rather than learners' achievement in taskbased performance. They controlled too much and often interfered into learners' activity which resulted in violating the principle of learner-centered approach. Teacher 1, for instance, organized a group work activity to carry out the tasks but (s)he quickly turned it into a more lockstep-type activity for explicit teaching. Similarly, this happened to teacher 2, too. On the whole, they strictly followed the given material and tried to solve the reading tasks in a way similar to what they did in the TTM condition, that was the teachers read the reading texts aloud to learners for comprehension and invited individual learner to answer each of the questions for accuracy achievement. The only difference that could be found in these teachers' classrooms was that instead of sitting alone, as in TTM, learners sat in groups and tentatively listened to the teachers' instruction. Compared to teachers 1 and 2, teacher 3 exploited the group work in a more effective manner. After putting learners into groups, the teacher allowed them to work on the tasks freely. In this respect, it is supposed that teacher 3 could offer learners more opportunities to invest their mental effort into the task and, at the same time, promote their interactive skills through interacting with their peers. However, teacher 3 failed to show his/her supporting roles while trying to help learners solve difficulties in communication. The teacher was seen unable to use strategic ways to support learners. Very often, (s)he came to learners who were in need and directly gave clear-cut answers to the problems. As such, the teacher could limit the learners' ability to discover the problems themselves. Also, the teacher dominated learners too much and this resulted in hindering learners' language development. Similar to teachers 1 and 2, teacher 3 set a strong focus on achieving accuracy although these teachers, prior the study, had been carefully trained that the priority of teaching, under a TBLT perspective, must be placed on meaningful communication. In fact, instead of encouraging learners to continue to perform the task, teacher 3 intentionally stopped the activity to move on task correction. For the rest of the phase, teacher 3 was fully devoted to teaching linguistic features and helping learners achieve accuracy.

In line with the task-performance phase, it does seem to indicate that all three teachers could not follow the post-task phase properly. In other words, they did not offer learners any chance to self-evaluate what they had learned. Also, the teachers did not summarize the learning output. It should be mentioned that none of the teacher applied principles of form-focused instruction and feedback-giving activities. Instead, they jumped to the closing stage directly (as in the TTM) to end the lesson after they had finished correcting the reading tasks in the material.

\subsection{Teachers' concerns of TBLT implementation}

Most teachers were highly aware that using TBLT, which claimed to place meaning as a priority, in the context of form-based syllabuses and assessment was a big challenge. Teacher 3 shared:

I have a doubt whether TBLT can help learners achieve high results in the exams which are still in favor of testing grammatical rules and vocabulary.

Similarly, teacher 1 said:

In case of dealing with highly academic texts (currently used in our teaching context) which require learners to place a great focus on accuracy, I think it is too challenging for learners if they are treated by TBLT.

With regard to learners, the teachers supposed that their learning attitudes were negative and they were too reluctant to follow TBLT. Teacher 2 described the learners as follow:

Learners were rather passive and shy in classroom discussion. They seemed to be reluctant to interaction with their peers and also with me. They preferred to listen, take notes and memorize what I said to them. Clearly, they aimed at achieving high results in the exams rather than participating in communication.

Teacher 1, in a similar vein, said:

I feel demotivated and even disappointed about the learners' learning attitudes. They just want to learn for getting a qualification, without considering practical uses or the quality of what they have learned.

In addition, large sized classes were also reported as one of the considerable problems. Teacher 1 said:

I also think of the bad effect of large-sized classes in TBLT. Can you imagine that how you can manage a communicative activity well while you have to take care of a lot of students at the same time?

Teacher 2 also agreed that it was hard to follow TBLT in such a crowded class. (S)he shared:

In TBLT teaching, I have to spend much more time on closely observing and taking care of individual learners. By doing this, I can track learners' needs as well as their strengths and weaknesses in their learning. As a result, I can offer timely support whenever they need. However, it is not easy for me to do this task effectively in a crowded class.

\subsection{Teachers' beliefs towards the advantages of TBLT}

The results indicate that all teachers believed TBLT could promote interaction, resulting in increasing learners' language use ability. Teachers 1 said: 
The learners had to interact a lot or listen to their group members and, importantly, they had real purposes to do those activities. As a result, they could develop language proficiency naturally.

The learner-learner interaction was actually promoted in the TBLT classroom. I can see that learners enthusiastically involved in discussion and sharing information with their partners. I think that this can help promote the language use ability among learners. (Teacher 2)

In a similar vein, teacher 3 shared:

The learners, in the TBLT classroom, had a lot of opportunities to use the language in a communicative way. Through group work activity, I see that they were really excited and involved in the discussion and willing to interact with their peers.

In addition, the three teachers admitted that TBLT classrooms could make the learning atmosphere much more comfortable. This could result in learners' high interest and motivation. Teacher 1, for example, said:

The learners did not work with pressure. They were not shy anymore and interestingly they dared to ask for help.... I personally think that learners were more enthusiastic and involved in their learning.

Similarly, teacher 3 said:

What I realize in the TBLT classroom is that the learners were active and highly motivated. They talked more and were willing to share ideas with their classmates.

\subsection{Teachers' beliefs towards the possibility of TBLT implementation and suggestions for an improvement}

All teachers reported that the implementation of TBLT was surely possible if the following changes could be considered.

First, there should be a must change in the teaching syllabus and the textbooks which should be in favor of TBLT. Teacher 1 suggested:

I think that the current teaching syllabus relies heavily on forms which might not suitable for a TBLT approach. So, if we want to implement TBLT, first and foremost, there must be a change in the teaching syllabus, then the textbooks which must be in favor of TBLT principles.

In the same vein, teacher 3 supposed:

The teaching syllabus has to be changed towards the TBLT approach. It means that the teaching contents must be shifted from a form-based focus to a meaning-based focus.

Second, it is important to take assessment into consideration. In this respect, teacher 2 said:

Current forms of assessment mainly measure learners' ability in achieving linguistic rules and vocabulary. Therefore, the learners have to focus strongly on those form-related items to achieve high scores in their exams. In fact, it is extremely difficult for the teacher to pursue TBLT unless a change in assessment must be taken into account.

Teacher 1 also shared a similar opinion, stating that:

I think assessment plays an extremely important role in deciding both teachers and learners' actions. For the teachers, they have to strictly follow the teaching syllabus required by the school. For the learners, they have to achieve high results in their study. If the learners want to achieve high results, they need to perform well in the testing papers. This implies that learners must pay much attention to the content which can be assessed in the exams. Therefore, if we can change the assessment (method and content), immediately the teachers and students will change afterwards.

Similarly, teacher 3 suggested as follow:

In order to change learners' awareness in learning, first and foremost, policy makers need to change the assessment methods. I think assessment has a significant impact on deciding what both the teacher and learners do in their teaching and learning practice.

\section{Discussion}

The current study investigates how the in-service teachers reacted to TBLT training in their actual teaching practices. The results offer glimpses of to what extent the principles of TBLT can be transferred and integrated into their teaching and also describe how the teachers manage their roles while performing TBLT. The semi-structured interview data show the teachers' attitudes towards TBLT including concerns, advantages, and its possibilities. Accordingly, possible implications for the improvement of a TBLT training program can be suggested.

The findings show that most teachers failed to pursue principles of meaning-based instruction and learner-centered focus thoroughly throughout the lesson. The reasons behind this could be explained in the great influence of traditional form-based teaching methods and syllabuses, on teachers' beliefs which in turn decided their actions (Hu, 2002; Chow \& Mok Cheung, 2004; Gorsuch, 2000). Teacher 1, for example, revealed in the semi-structured interview that one of the most challenging tasks when implementing TBLT was how to achieve meaning-based focus while the teaching syllabus was said to prioritize form-based accuracy. Therefore, it is, first and foremost, necessary to suggest that changes in the current language teaching syllabus towards TBLT 
should be taken into account. By doing this, teachers can offer learners more opportunities and conditions to work with communicative tasks resulting in enhancing the language use ability. With regard to the principle of learner-centered focus, the teachers did not dare to allow learners to decide their own learning progress, but tended to over-control and interfere into learners' activities. Moreover, the results indicate that the teachers chopped up the language into discrete units for explicit teaching and this, unexpectedly, strongly violated the principle of holistic teaching in TBLT. For these violations, it could be explained that the teachers may not receive enough sufficient training towards the use of these principles (Barnard \& Nguyen, 2010). Thus, they might lack confidence and necessary skills to pursue them (Morris, 1996; C. Y. Li, 2003; Kam, 2004). Therefore, it is suggested that policy makers need to invest in a more consistent and long-term trajectory of professional development for teachers. Instead of providing additional resources or one-shot training program, a gradual, careful and evolutional training should be encouraged.

Similarly, teachers could not be able to apply the principles of form-based focus and teacher-led allowance into their teaching practice although they, prior to the study, had been carefully trained about these principles. The teachers, in general, preferred either to explain vocabulary and individual linguistic features to learners explicitly or to keep going on the lesson without considering the problems that learners were facing to. The reasons for this could be the result from the great influence of traditional teaching methods (as discussed above). Another possible explanation could be that the training program is not sufficient enough to convince the teachers to follow. Therefore, they are reluctant to follow it. In view of the fact that as many as $75 \%$ of all innovations fail into long-term effect (Markee, 1997; Adam \& Chen, 1981) mainly because most adopters who were trained towards those innovations do not follow. Rather, they rely on their collective and individual experience (Cochran-Smith \& Lytle, 1993) or they prefer to modify the task which they think is best for their teaching and learners (Van den Branden, 2016). Therefore, it is suggested for a future training program that it should not be too ambitious, but evolutionary (Carless, 1997). Moreover, sustainable changes towards TBLT, which can be done, for instance, by combining both in-service trainings and the introduction of TBLT courses into the teaching syllabus (Linsen, 1994 as cited in Van den Branden, 2006) can be helpful.

Regarding possible concerns in case of implementing TBLT, most teachers complained about the current teaching syllabuses and assessment which, according to them, focused heavily on form-based instruction while the teachers, in a TBLT perspective, have to follow meaning-based teaching. It is suggested that policy makers and educational leaders have to make a careful and thorough investigation into current language teaching needs in order to make appropriate changes. In addition, the teachers claimed that they could not implement communicative and learner-oriented activities effectively due to the learners' negative learning attitudes. The reason for this could be explained in the great impact of assessment which mainly aims at measuring learners' achievement in accuracy, regardless of learners' language use ability in communication. Therefore, most learners seem to ignore communicative goals in their learning. It is implicated that educational leaders need to think of a change in assessment methods. Finally, large sized classes were reported as a serious problem hindering the implementation of TBLT. However, it seems that these teachers fail to realize one of the benefits of TBLT, that is it can offer great opportunities for peer interaction and for individual task-based work, even in large-size classes. This implies that the teachers need to be supported with regard to class management skills.

With regard to the advantages of TBLT, all teachers agreed that TBLT could help learners enhance language use ability. In view of the fact that TBLT follows meaning-based and learner-centered education which allows learners to interact and exchange information with their peers very often. Through communicating in real-life target tasks, learners can effectively develop their language use ability. Furthermore, the teachers admitted that TBLT could make the learning atmosphere more comfortable. In fact, TBLT can potentially activate the learning needs and interests, resulting in the enhancement of learners' intrinsic motivation (Cheng \& Mose, 2011; Tabatabaei \& Hadi, 2011).

The results also reveal that all teachers strongly believed in the possibility of TBLT if the following suggestions can be considered. First, a must-change in the teaching syllabus and the textbooks from a formbased focus to meaning-based focus should be taken into consideration. Second, traditional assessment methods which are in favor of linguistic accuracy should be replaced by TBLT assessment which considers criterionreferenced tests as heart of source for evaluation. In addition, the large number of learners in classrooms was reported as a big challenge for the implementation (D. F. Li, 1998; Carless, 2004). Therefore, it is necessary for educational leaders and policy makers to consider it and find out the best solutions. Besides other related-factors impacting the adaptation of TBLT, the learner factor contributes a great effect (Lee, 2005). Clearly, it is learners, who have been heavily influenced by the TTM, are extremely passive, attentive and reluctant to participate in discussion or share ideas. This, consequently, might cause failure in TBLT implementation. It is, therefore, suggested that considering learners as a real change agent in the innovation by offering them more opportunities to be involved in interactive activities, both inside and outside classroom environment can be a solution. Also, listening to what the learners actually need can help the teachers, on the one hand, to find out the 
right solutions to deal with learners' needs, and on the other hand, to encourage them to be actively involved in their own learning.

\section{Conclusion}

In summary, the overall results show that the in-service teachers could not properly transfer the theoretical knowledge of TBLT (including TBLT principles and the role of the teacher) that they had acquired during the training program to their authentic classrooms. Instead, they preferred to turn into traditional teaching as a secure solution due to a number of reasons (as discussed above). Among those, the heavy influence of traditional teaching methods as well as current form-based teaching curriculum and assessment is believed to be problematic. In addition, the lack of a sufficient training program is also one of the main reasons for the failure. Despite those difficulties, the semi-structured interviews also reveal promising data. It is indicated that all teachers believed that TBLT had a lot of positive characteristics which seem to match very well with the current needs of language learning and teaching in Vietnam. They supposed that TBLT could be successfully implemented if necessary changes were taken into consideration. Therefore, it is important for all related agents (policy makers, syllabus designers, test-makers, trainers, teachers, learners, etc.) to make a change in case of promoting TBLT implementation. It should be noticed that teachers always play a key role in such an innovation. Therefore, training teachers to apply TBLT into their teaching practice is extremely important. If this task cannot be done properly, any changes in language teaching will not be possible.

It is worth noting that limitations associated with this study are unavoidable. Firstly, the number of participants in this study is too small. Three teachers are not enough to be generalized to an overall conclusion. Secondly, the treatment time, which is limited to two 90-minute-lessons teaching is too short. It is suggested for future research that more participants should be involved and a longer treatment time should be considered. In addition, the current study tried to examine the teachers' application of TBLT into their teaching practice but not to investigate teachers' perceptions towards the training. Therefore, future research exploring in-service training teachers' perceptions towards TBLT training is needed.

[1] Thornbury, S.(1999). How to teach grammar. Harlow: Longman.

[2] Skehan, P. (2003). Task-based instruction. Language teaching, 36 (1), 1-14.

[3] Ellis, R. \& Shintani, N. (2014). Exploring Language Pedagogy through Second Language Acquisition Research. London, England: Routledge.

[4] Ellis, R. (2003). Task-Based Language Learning and Teaching. Oxford: Oxford University Press.

[5] Wong, H., \& Van Patten, B. (2003). The best English: A claim for the superiority of received standard English. Society for Pure English, 39, 603-21.

[6] Ministry of Education and Training [MOET] (2006). Chuong trinh giao duc pho thong: Mon Tieng Anh [English curriculum for the secondary school]. Hanoi, Vietnam: Education Publishing House.

[7] Markee, N. (1997). Second language acquisition research: A resource for changing teachers' professional cultures? The Modern Language Journal, 81 (1), 80-93.

[8] Borg, S. (2003). Teacher cognition in language teaching: A review of research on what language teachers think, know, believe, and do. Language Teaching, 36, 81-109.

[9] Van den Branden, K. (2009a). Diffusion and Implementation of Innovations. In Long, M. H., \& Doughty, C. J. (Ed.). The Handbook of Language Teaching, 559-672. Oxford: Blackwell Publisher.

[10] Long, M. (1985). A role for instruction in second language acquisition: Task-based language teaching. In K. Hylstenstam \& M. Pienemann (Eds.), Modelling and Assessing Second Language Acquisition (pp. 77-79). Clevedon: Multilingual Matterns.

[11] Long, M. (2015). Second Language Acquisition and Task-Based Language Teaching. Sussex, UK: Wiley Blackwell.

[12] Van den Branden, K. (2006). Task-based language education: From theory to practice. Cambridge: Cambridge University Press.

[13] Van den Branden, K., Bygate, M., \& Norris, J. (2009). Task-based language teaching: A reader. Amsterdam: John Benjamins.

[14] Van den Branden, K. (2016). Task-based language teaching. In G. Hall (Eds.), The Routledge Handbook of English Language Teaching, 238-252. New York: Routledge.

[15] Ellis. R. (2009). Task-based language teaching: Sorting out the misunderstandings. International Journal of Applied Linguistics, 19 (3), 221-246

[16] Norris, J. M. (2009). Task-based teaching and testing. In M. Long and C. Doughty (Eds.), Handbook of language teaching (pp. 578594). Cambridge: Blackwell.

[17] Norris, J. M. (2016). Current Uses for Task-Based Language Assessment. Annual Review of Applied Linguistics, 36, 230-244

[18] Brindley, G. (1994). Task-centered assessment in language learning: the promise and the challenge. In N. Bird, P. Falvey, A. Tsui, D. Allison \& A. McNeill (Eds.), Language and learning: papers presented at the Annual International language in Education Conference (Hong Kong, 1993), 73-94. Hong Kong: Hong Kong Education Department.

[19] Paltridge, B. (1992). EAP placement testing: an integrated approach. English for Specific Purposes, 11, $243-268$.

[20] Cochran-Smith, M., \& Lytle, S. (1993). Inside outside: Teacher research and knowledge. New York: Columbia University Teachers College Press.

[21] Bailey, K. M. (1992). The process of innovation in language teacher development: What, why and how teachers change. In Flowerdew, J., Brock, M., \& Hsia, S. (Eds.), Perspectives on second language teacher development (p. 253-282). Hong Kong: City Polytechnic of Hong Kong.

[22] Borg, M. (2001). Key concepts in ELT: Teachers' beliefs. ELT Journal, 55 (2), 186-188

[23] Van den Branden, K. (2009b). Mediating between predetermined order and complete chaos. The role of the teacher in task-based language education. International Journal of Applied Linguistics, 19 (3), 264-285.

[24] Hattie, J. (2012). Visible learning for teachers: Maximizing impact on learning. New York, NY: Routledge. 
[25] Vongalis-Macrow, A. (2007). I, teacher: Re-territorialization of teachers' multi-faceted agency in globalized education. British Journal of Sociology of Education, 28(4), 425-439.

[26] Prabhu, N. S. (1987). Second language pedagogy. Oxford: Oxford University Press.

[27] Willis, J., \& Willis, D. (1996). Challenge and change in language teaching. Oxford, UK: Macmillan Heinemann.

[28] Samuda, V. (2001). Guiding relationships between form and meaning during task performance: The role of the teacher. In M. Bygate, P. Skehan, \& M. Swan (Eds.), Researching pedagogic tasks: Second language learning, teaching and testing (p. 119-140). Harlow, UK: Longman.

[29] Adamson, B., \& Davison, C. (2003). Innovation in English language teaching in Hong Kong primary schools: One step forward, two steps sideways? Prospect, 18 (1), 27-41.

[30] Zhang, E. (2007). TBLT-innovation in primary school English language teaching in mainland China. In K. Van den Branden, K. Van Gorp, \& M. Verhelst (eds.), Tasks in action: Task-based language education from a classroom-based perspective (pp. 68-91). Cambridge: Cambridge Scholar Publishing.

[31] Samuda, V., \& Bygate, M. (2008). Tasks in second language learning. Houndmills, New York: Palgrave Macmillan.

[32] Barnard, R. \& Nguyen, V. G. (2010). Task-Based Language Teaching (TBLT): A Vietnamese Case Study Using Narrative Frames to Elicit Teachers' Beliefs. Language Education in Asia, I, 77-86.

[33] Littlewood, W. (2007). Communicative and task-based language teaching in East Asian classrooms. Lang. Teach, 40, 243-249.

[34] Hu, G. (2002). Recent Important Developments in Secondary English-language Teaching in the People's Republic of China. Language, Culture and Curriculum, 15 (1), 30-49.

[35] Chow, A. K. W., \& Mok-Cheung, A. H. M. (2004). English language teaching in Hong Kong SAR: Tradition, transition, and transformation. In H. W. Kam \& R. Y. L. Wong (Eds.), Language policies and language education: The impact in East Asian countries in the next decade (pp. 150-177). Singapore: Times Academic Press.

[36] Gorsuch, G. J. (2000). EFL educational policies and educational cultures: Influences on teacher's approval of communicative activities. Tesol Quarterly, 34 (4), 675-710.

[37] Morris, P. (1996). The Hong Kong school curriculum: Development, issues and policies. Hong Kong: Hong Kong University Press.

[38] Li, C. Y. (2003). A study of in-service teachers' beliefs, difficulties and problems in current teacher development programs. $H K B U$ Papers in Applied Language Studies 7, 64-85.

[39] Kam, H. W. (2004). English Language Teaching in East Asia Today: An Overview. Asia Pacific Journal of Education, 22 (2), 1-22.

[40] Adams, R. \& Chen, D. (1981). The process of educational innovation: An international perspective. London: Koran Page in association with Unesco Press.

[41] Carless, D. (1997). Managing systematic curriculum change: a critical analysis of Hong Kong's target-oriented curriculum initiative. International Review of Education, 43, 349-366.

[42] Linsen, B. (1994). Met vallen en opstaan: de introductie van taakgericht taalonderwijs. Een praktijkbeschrijving uit het basisonderwijs in Vlaanderen. In S.Kroon \& T. Vallen (eds.), Nederlands als tweede taal in het onderwijs. Parktijkbeschrijvingen uit Nederland en Vlaanderen (pp. 131-159).

[43] Cheng, X., \& Mose, S. (2011). Perceptions and Implementation of Task-based Language Teaching among Secondary School EFL Teachers in China. International Journal of Business and Social Science, 2 (24), 292-302.

[44] Tabatabaei, O., \& Hadi, A. (2011). Iranian EFL Teachers' Perceptions of Task-Based Language Pedagogy. Higher Education of Social Science, 1 (2), 1-9.

[45] Li, D. (1998). "It's always more difficult than you plan and imagine": Teachers' perceived difficulties in introducing the communicative approach in South Korea. TESOL Quarterly, 32, 677-697.

[46] Carless, D. (2004). Issues in teachers' re-interpretation of a task-based innovation in primary schools. TESOL Quarterly, 38 (4), 639-662.

[47] Lee, S. M. (2005). The pros and cons of task-based instruction in elementary English classes. English teaching, 60, 185-205.

Appendix 1 - Semi-structured interview

APPENDICES

Question 1: What do you think when teaching by 2 different methods: TBLT and TTM?

Question 2: What are the strong and weak points of TBLT compared to TTM? 
In-service teachers' reaction to a training program of Task-based language teaching: A case study..

Question 3: What do you think about the possibility of TBLT implementation in Vietnam?

Question 4: What changes should be made in order to promote the implementation of TBLT successfully?

\section{Appendix 2 - Teaching material}

\section{NHA TRANG}

Nha Trang is one of the most important tourist hubs of Vietnam, thanks to its beautiful beaches with fine and clean sand and the clear ocean water with mild temperatures all year round. There are several resorts - such as Vinpearl, Diamond Bay and Ana Mandara - and water parks, in the city and on islands off the coast. The possibly most beautiful street of Nha Trang is Tran Phu Street along the seaside, sometimes referred to as the Pacific Coast Highway of Vietnam.

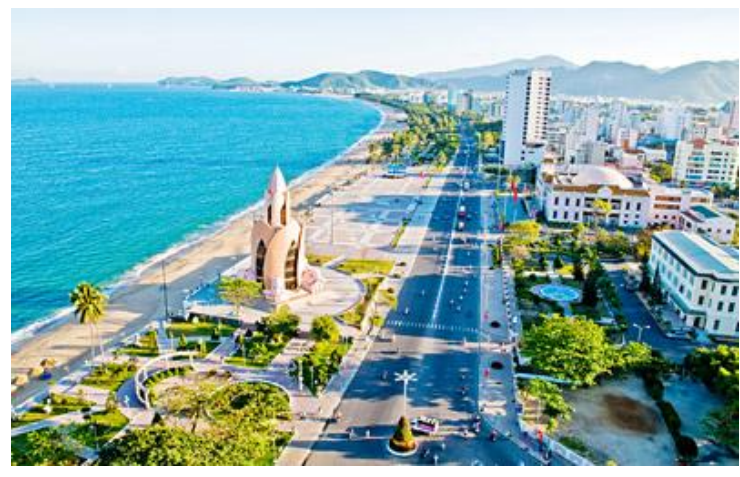

Nha Trang is a stopover for annual yacht races starting in Hong Kong. In recent years, the city has welcomed many five-star sea cruises. In addition to sailboat racing, Nha Trang provides a rich variety of tourist activities for visitors. Island hopping, scuba diving, water sports and other sporting activities can be enjoyed. The Nha Trang Tourist Information Center (a non-governmental organisation), located near the Cho Dam Market has been set up to provide information for visitors.

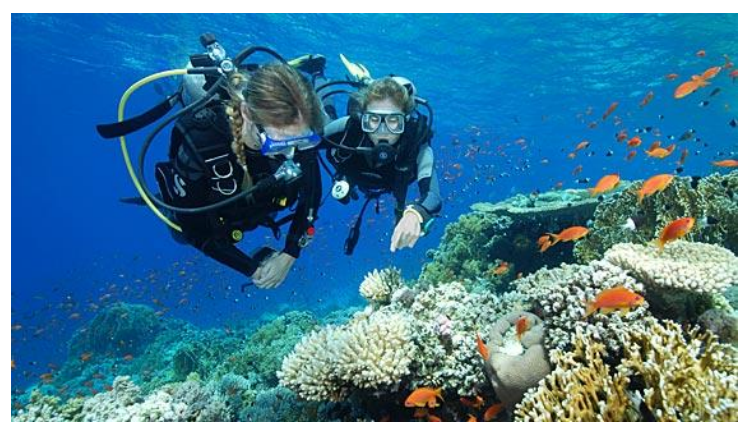


The local cuisine is most famous for fresh seafood and barbecued pork rolled in rice paper. The area's bird's nest soup is deemed one of the best in Vietnam. Bird's nests are collected in the wild, on bird farms on the islands off the coast and even in some houses in the inner city.

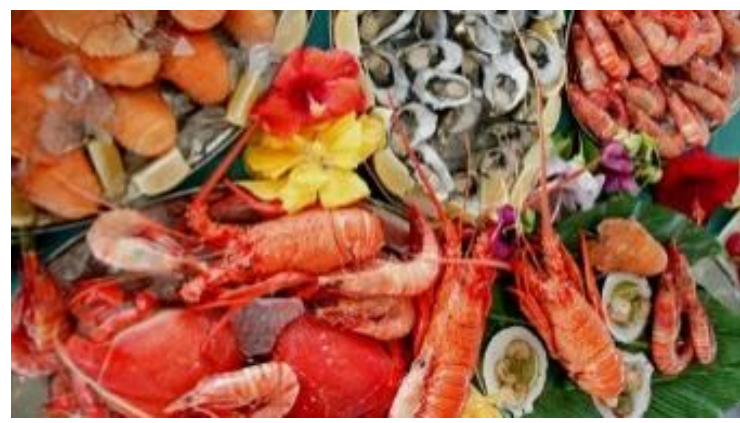

\section{QUESTIONS}

\section{True/False statements}

1. ___ Nha Trang is very hot, especially in the summer time.

2. __ Tran Phu is the name of a very famous Highway street in Vietnam.

3. __ There are many recreational activities that tourists can do in Nha Trang.

4. ___ In Nha Trang, tourists can try seafood and beefsteak in local's houses.

5. B__ Bird's nest soup is very famous in Nha Trang.

\section{SAPA}

Sa Pa District is located in Lào Cai Province, north-west of Vietnam, and $380 \mathrm{~km}$ north-west of Hanoi, close to the border with China. Sa $\mathrm{Pa}$ is a quiet mountain town and home to a great diversity of ethnic minority peoples. The geographical location of the area makes it a truly unique place for many interesting plants and animals, allowing it to support many inhabitants. Many very rare or even endemic species have been recorded in the region.

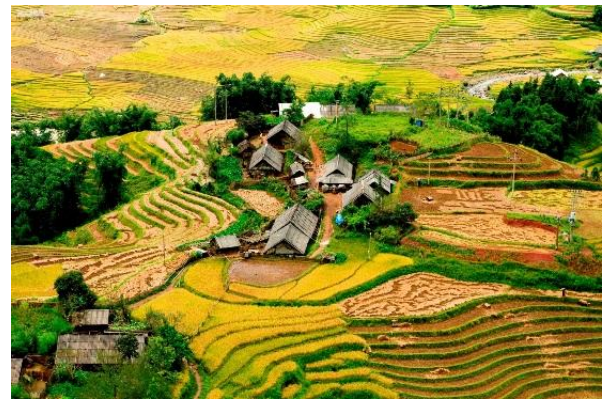

Cat Cat village is a must-visit place in Sapa, especially for couples. In the fresh and decent atmosphere of this village, no one knows what level their love can reach to. Moreover, vegetable and mushroom here are the best of Vietnam. Tourists can also visit Dragon Mouth Mountain (Ham Rong), a mountain full of magnificent scenes, fountains and green fields. Moreover, Bac Ha market is a perfect place for trading unique clothes and jewelry of highlands. And if you want to challenge yourself, Fansipan peak with $3143 \mathrm{~m}$ height surely can fulfill your desire.

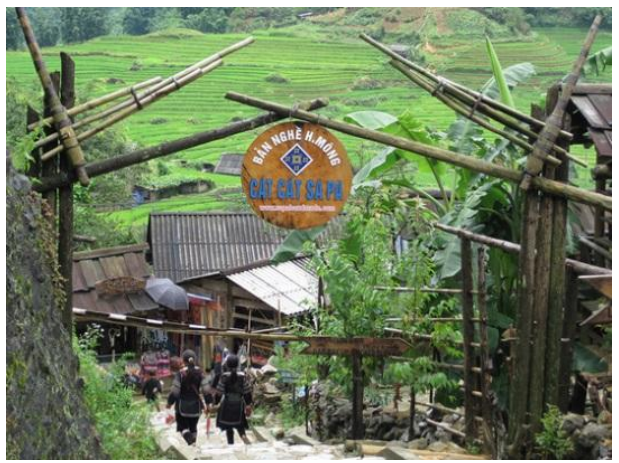


Ta Phin is the nearest village of Red Dao's ethnic group within the area of Sapa district. From Sapa, it will take about 30 minutes to reach here by motorbike. The mountainous road can make it difficult for cars to move, so the best solution is to hire a "xe om", or motorbike taxi, and the experienced driver will take you to right place at a very reasonable price with many useful advice and tips.

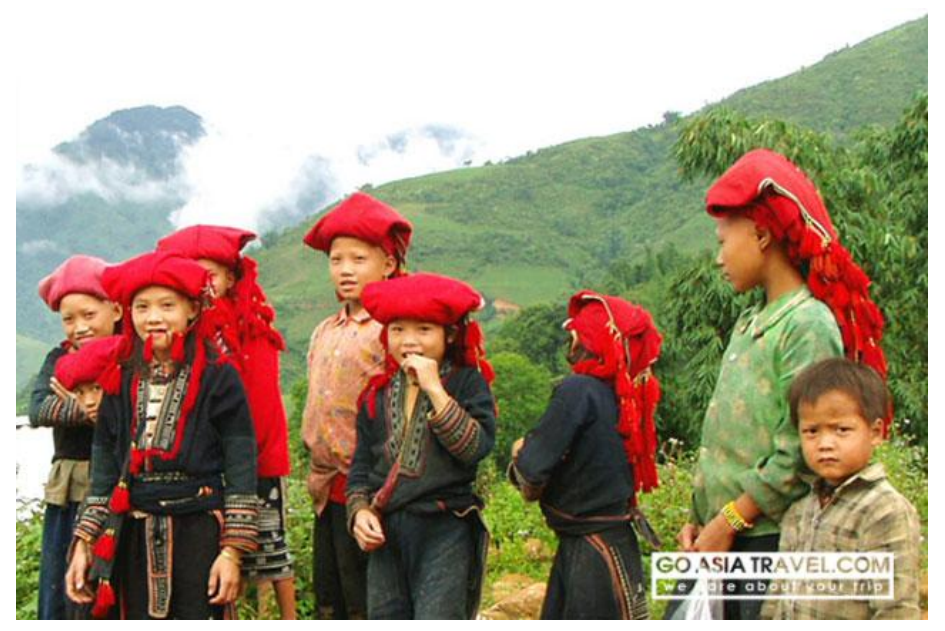

Coming to Ta Phin, you will immediately catch sight of groups of Red Dao's women gathering together, keeping inside their hands colorful reels of thread and cloths. They sew continuously, even when offering the goods to the customers. Amazingly, most of them can speak quite well, some use Vietnamese less than English. Since 1998, Ta Phin has officially become the "brocade village", where tourists can find the distinctively hand-made brocades made by ethnic people. All of the products are eye-catching with numerous bright colors and patterns, ranging from bag, scarf, purse, to skirt, and even backpack and coat. Ta Phin is also the main supply of brocades for shops in Hanoi and Ho Chi Minh City, and the products are exported to foreign countries as well. There are also several local festivals such as "dancing festival", "greeting for the new house" that will help you understand more about the simple but happy life of ethnic people.

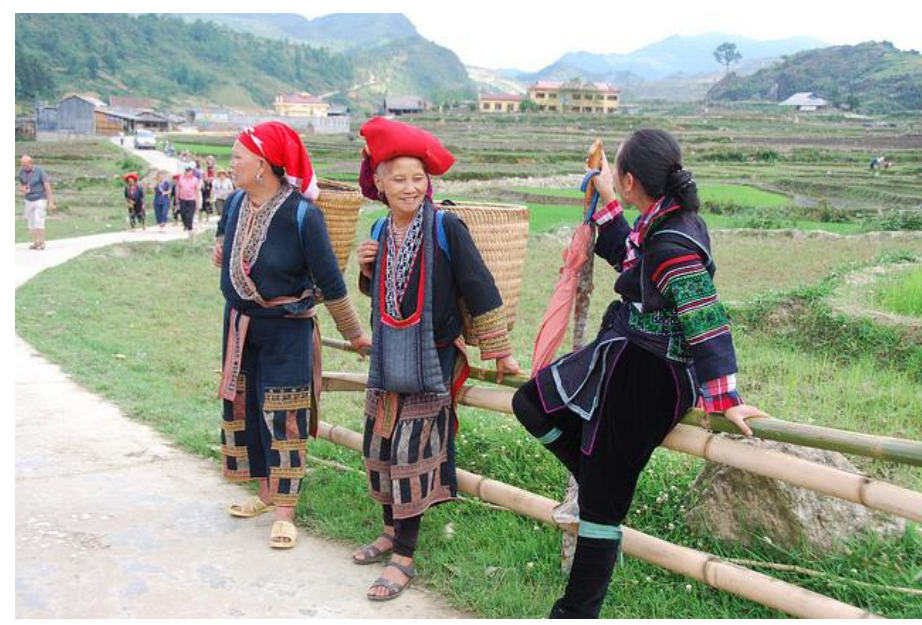

\section{QUESTIONS}

\section{Choose the correct answers for the following questions}

1. What can be inferred from the reading?

a. Sapa is a great place for tourists to meet different kinds of people coming from different parts of the country.

b. Sapa is considered as one of the most crowded places of population who love living in the nature.

c. Sapa is a good place to meet different kinds of ethnic minority peoples.

d. Sapa is too quiet to be the most favorite tourism destination.

2. What does the writer want to say about Sapa?

a. Tourists can enjoy a variety of entertainment activities when visiting Sapa such as hiking, watching animals and fishing. 
b. Sapa is never a boring place, especially to newcomers because it offers all kinds of cultural activities performed by experts and famous people in the country.

c. In Sapa tourists can buy unique clothes and jewelry of highlands, but should never try to challenge themselves to climb to Fansipan peak because of its danger.

d. Tourists can hire a motorbike-taxi to get around Sapa, but not a car because driving car is supposed to be dangerous in the mountainous area.

3. What can tourists do in Sapa?

a. They can meet a lot of Red Dao' women in Cat Cat village.

b. Tourists can hire a taxi to go around for a visit with a very reasonable price.

c. Tourists can try the best local foods, especially mushrooms and vegetables.

d. They can visit the zoo where many endemic species are being kept.

4. In Sapa, tourists can
a. go hiking
b. go swimming
c. go skiing
d. go shopping

5. The main theme of this article is

a. to introduce Sapa to people

b. to investigate what Sapa has

c. to insist people to help ethnic minority peoples

d. to stop people from doing harmful activities to Sapa

\section{HOI AN}

Hoi An is a city in Vietnam, located on the coast of the South China Sea in the South Central Coast region, in Quang Nam Province.

Due to the increased number of tourists visiting Hoi An, a lot of of activities are emerging which allow guests to explore this land by motorbike, bicycle, kayak or motorboat. The Thu Bon River is still essential to the region more than 500 years after António de Faria first navigated it and still remains an essential form of food production and transport.

The city has four museums highlighting the history of the region. These museums are managed by the Hoi An Center for Cultural Heritage Management and Preservation. Entrance to the museum is permitted with a Hoi An Entrance Ticket.

Hoi An is known for its great food, fun shopping, skilled tailors, friendly people and cozy atmosphere - all key characteristics that draw people to this picturesque town.

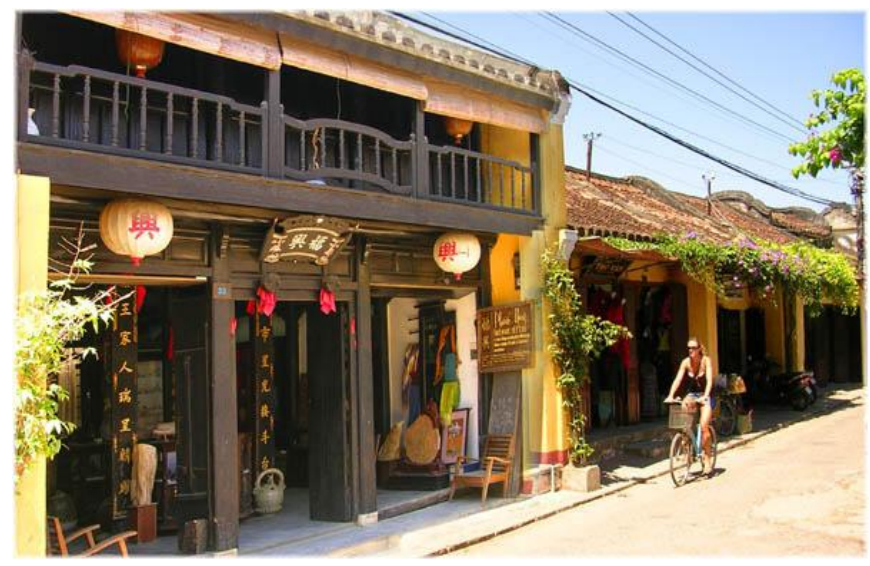

The Old Town - Two great things about Hoi An's Old Town are that it is small enough to get around in on foot and the traffic is not as heavy as in bigger cities. Some of the streets only allow bike and motorbike traffic and some are for pedestrians only. These factors make Hoi An even more inviting for most travelers to Vietnam. Moreover, many buildings in the Old Town were constructed over a century ago and feature strong Chinese influences stemming from merchants from Guangzhou, Fujian, Chiu Chow and Hainan. Some of the wooden signboards bearing the company names are carved and gilded in Chinese characters, reflecting the strong presence of the Chinese in Hoi An ever since its prosperous times.

Nightlife in Hoi An's Old Town is not extremely hectic and things usually get quiet after 22:00. Still, travelers can easily find a place or two to hang out and enjoy a few drinks, snacks or a game of pool and darts. 


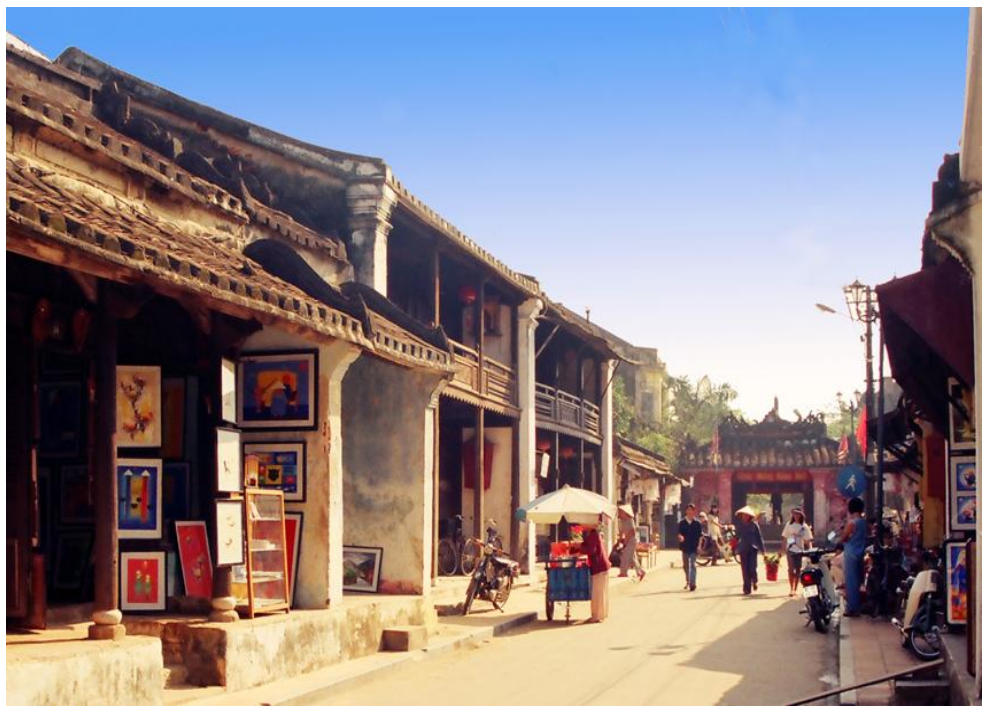

\section{QUESTIONS}

1. Where is Hoi An located?

2. What can tourists do in Hoi An?

3. What do tourists need to do if they want to get inside museums in Hoi An?

4. What are two great things about Hoi An's Old Town?

5. What can tourists do at night in Hoi An?

\section{MEKONG DELTA}
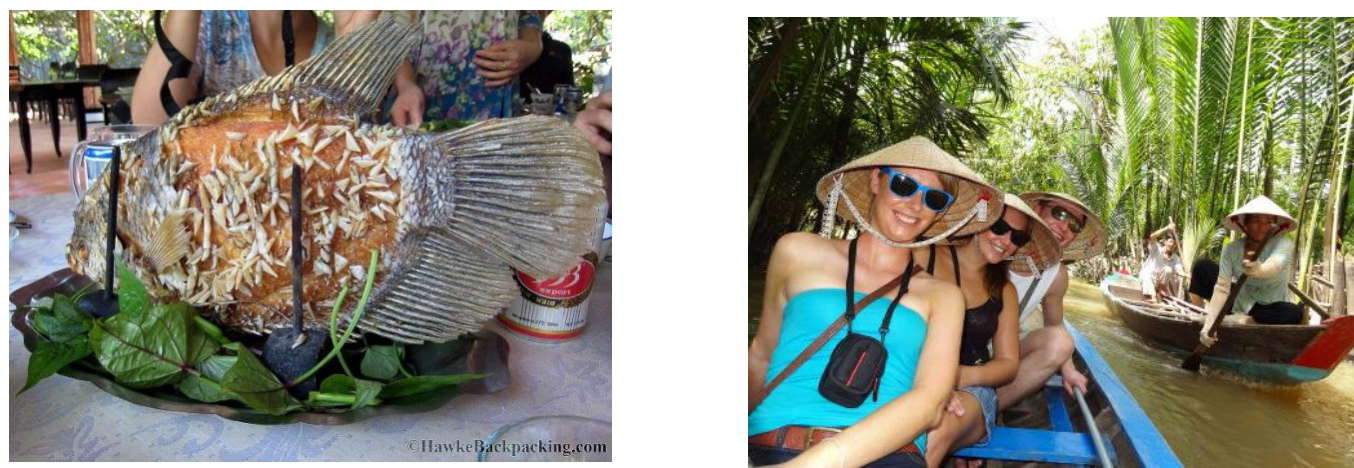

A. The Mekong Delta in southern Vietnam is a vast maze of rivers, swamps and islands, home to bird sanctuaries, fascinating villages, endless fruit gardens, floating markets and pagodas surrounded by rice paddies. Boats are the main means of transportation, and tours of the region often start in nearby Ho Chi Minh City (formerly known as Saigon) or Can Tho, a bustling town in the heart of the delta.

B. A typical one-day trip from Ho Chi Minh City is not merely enough for you to explore the most fertile region of the country. There is no place else in Vietnam where you can enjoy such an abundance of fruits, vegetables and river fish of all kinds. There is an endless list of treats to local taste, but do your best to try the fish hotpot, grilled snails in black pepper sauce and the famous Ben Tre coconut.

C. If you have a chance to stay with a local family then don't be surprised (and shouldn't refuse) when the host just gets everything they can find in the house (or in the market) to treat you to a proper feast. Warm and sincere 
In-service teachers' reaction to a training program of Task-based language teaching: A case study..

hospitality is the core nature of Mekong people. Pamper yourself with cruising the delta at dusk, dining with grilled fish and enjoying a refreshing beverage while watching the sunset - it's about as good as it gets.
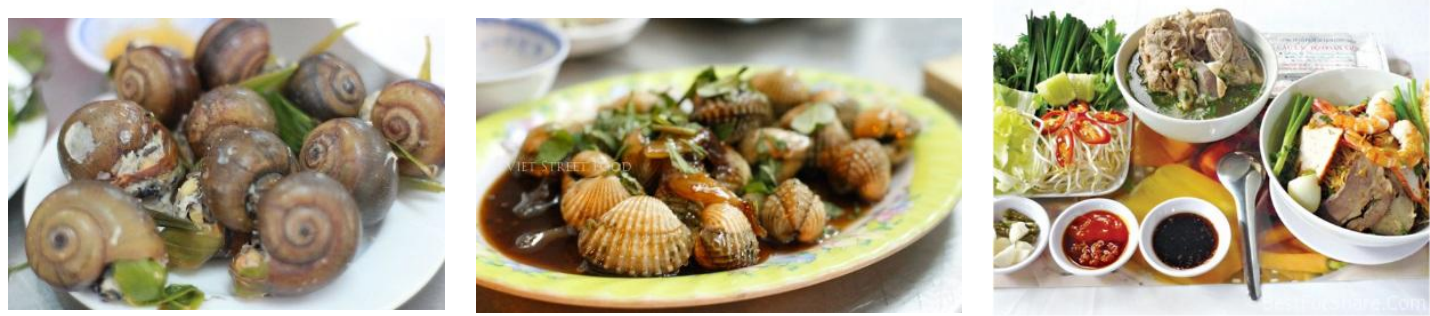

\section{QUESTIONS}

Choose the best headings for the paragraphs

1. Interesting activities that tourists can discover in the Mekong Delta

2. What happen if tourists visit the Mekong Delta

3. General information of the Mekong Delta that tourists can have a look

4. The hospitality of people in the Mekong Delta

5. What tourists should and shouldn't do in the Mekong Delta

Paragraph A

Paragraph B

Paragraph C

\footnotetext{
Nguyen Anh Thi. "In-service teachers' reaction to a training program of Task-based language teaching: A case study of English language teachers in Vietnam ." IOSR Journal of Research \& Method in Education (IOSR-JRME) 7.3 (2017): 53-68.
} 